\title{
A possible role for electron microscopy in detection of carriers of Duchenne type muscular dystrophy ${ }^{1}$
}

\author{
A. K. AFIFI, ${ }^{2}$ R. A. BERGMAN, AND H. ZELLWEGER \\ From the Department of Human Morphology, School of Medicine, American University of Beirut, \\ Lebanon; The Department of Anatomy, Johns Hopkins School of Medicine, Baltimore, U.S.A.; \\ and The Department of Pediatrics, School of Medicine, University of Iowa, Iowa City, Iowa, U.S.A.
}

SUMMARY Five carriers of the gene of Duchenne type muscular dystrophy are described. Muscle histology was minimally to moderately abnormal in two and normal in three. Electron microscopy was abnormal in all five and showed massive aggregates of subsarcolemmal mitochondria, paracrystalline mitochondria, $\mathrm{Z}$ line streaming, central nuclei, dilated sacs of sarcoplasmic reticulum, focal loss of myofilaments, and lipid lysosome bodies. The electron microscopic literature on the carrier state is reviewed and analysed. The possible role of electron microscopy in detection of carriers is discussed.

In a disease relentlessly progressive with X-linked inheritance such as Duchenne type muscular dystrophy (DMD), carrier detection becomes an important requirement for accurate genetic counselling. To this end several methods of investigation have been or are being developed. Serum enzyme determination, muscle isoenzymes, electromyography (EMG), and muscle biopsy, separately or in combination, have led to detection of a good number but not all carriers of the gene for Duchenne type muscular dystrophy. The purpose of this report is to explore the value of electron microscopy in carrier detection. The units used for enzyme estimation are listed under Table 1.

\section{CLINICAL DATA}

CASE 1 M.J. (see Fig. 1, $\mathrm{III}_{4}$ ) is a 9 year old clinically normal female. Her brother was a sporadic case of DMD, whose myopathy was first noted at the age of 5 years. He was seen at the age of 15 years in an advanced state of the disease, from which he died at 17 years of age. Electromyograms, serum enzymes, and muscle biopsy were compatible with the clinical

\footnotetext{
1 Supported by grant no. 18-5104 from the Medical School Research Fund, American University of Beirut. (A.K.A.), grant no. 38-1716 from the Common Wealth Fund and grant no. NIH (NINDS) NBO4096 from the Public Health Service (RAB).

2 Address for reprints: Dr. Adel K. Afifi, Department of Human Morphology, American University of Beirut, Beirut, Lebanon.
}

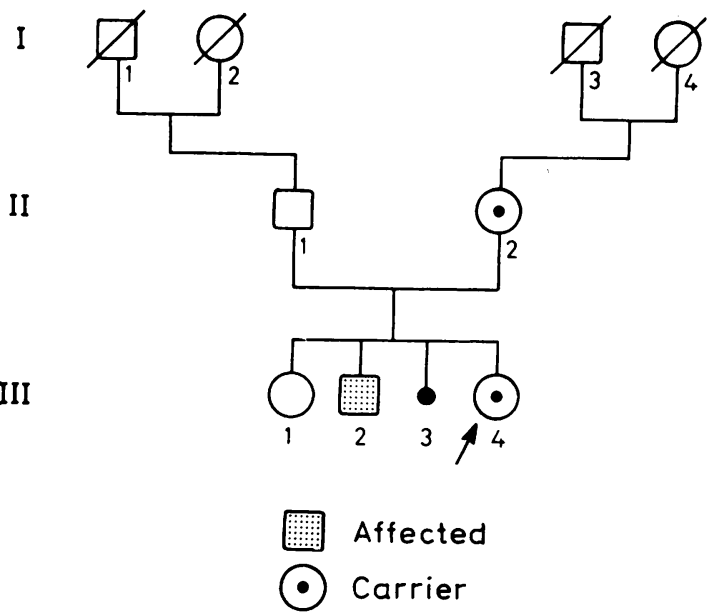

FIG. 1. Family pedigree of case 1, M.J. (arrow).

diagnosis of DMD. The serum of his 44 year old mother was examined on three occasions. Creatine phosphokinase (CPK) levels were between 3.0 and 5.0 i.u. with a mean of 3.7 (mean $+2 \mathrm{SD}$ of normal controls of same age $2 \cdot 3 \pm 2$ ). Serum aldolase varied between 3.6 and 11.3 units with a mean of 7.5 units (normal mean \pm 2 SD. $5 \cdot 1 \pm 2$ ). Serum glutamic oxalotransaminase (SGOT) and lactic dehydrogenase (LDH) (one determination only) were within normal limits. 
TABLE 1

SERUM ENZYMES

\begin{tabular}{|c|c|c|c|c|c|}
\hline & $\begin{array}{l}\text { Age } \\
(y r)\end{array}$ & $\begin{array}{l}\text { SGOT } \\
\text { (units) }\end{array}$ & $\begin{array}{c}C P K \\
\text { (units) }\end{array}$ & $\begin{array}{c}L D H \\
\text { (units) }\end{array}$ & $\begin{array}{c}\text { Ald } \\
\text { (units) }\end{array}$ \\
\hline Case 1, M.J. & 9 & $\begin{array}{l}55 \\
74\end{array}$ & $\begin{array}{l}23 \cdot 6 \\
25\end{array}$ & $\begin{array}{l}530 \\
590\end{array}$ & $\begin{array}{l}16 \\
16\end{array}$ \\
\hline Case 2, P.C. & $8-10$ & $\begin{array}{l}31 \\
36\end{array}$ & $\begin{array}{l}18 \cdot 4 \\
27 \cdot 6 \\
16 \cdot 9\end{array}$ & $\begin{array}{l}780 \\
720\end{array}$ & $\begin{array}{c}7 \\
22 \\
8 \cdot 8\end{array}$ \\
\hline Mean & & & $21 \cdot 0$ & & $12 \cdot 6$ \\
\hline $\begin{array}{l}\text { Normal mean } \\
\pm 2 \mathrm{SD} \text { for } \\
\text { girls } 6-10 \text { yr }\end{array}$ & & $20 \pm 9$ & $3 \cdot 6 \pm 2 \cdot 6$ & $303 \pm 75$ & $6.6 \pm 3.8$ \\
\hline Case 3, E.W. & 21 & $\begin{array}{l}12 \\
14\end{array}$ & $\begin{array}{l}5 \cdot 2 \\
1 \cdot 7 \\
4 \cdot 5\end{array}$ & $\begin{array}{l}690 \\
360\end{array}$ & $\begin{array}{l}5 \\
4 \\
5\end{array}$ \\
\hline Mean & & & $3 \cdot 8$ & & $4 \cdot 7$ \\
\hline Case $4, \mathrm{M} . \mathrm{W}$. & 27 & $\begin{array}{l}12 \\
12\end{array}$ & $\begin{array}{l}3 \cdot 7 \\
2 \cdot 3 \\
3 \cdot 3\end{array}$ & $\begin{array}{l}340 \\
300\end{array}$ & $\begin{array}{l}3 \\
3 \cdot 7 \\
3\end{array}$ \\
\hline Mean & & & $3 \cdot 4$ & & $3 \cdot 2$ \\
\hline $\begin{array}{l}\text { Normal mean } \\
\quad+2 \text { SD for } \\
\text { women } 21-30 \mathrm{yr}\end{array}$ & & $13 \pm 4$ & $2 \cdot 9 \pm 2 \cdot 2$ & $161 \pm 74$ & $5 \cdot 1 \pm 2 \cdot 6$ \\
\hline Case 5, G.W. & 55 & $\begin{array}{l}16 \\
16\end{array}$ & $\begin{array}{l}15 \cdot 7 \\
20 \cdot 7 \\
12\end{array}$ & $\begin{array}{l}580 \\
330\end{array}$ & $\begin{array}{l}8 \\
6 \\
7 \cdot 4\end{array}$ \\
\hline Mean & & & $16 \cdot 1$ & & $7 \cdot 3$ \\
\hline $\begin{array}{l}\text { Mean } \pm 2 \text { SD for } \\
\text { normal women } \\
\text { over } 40 \mathrm{yr}\end{array}$ & & $14 \pm 4$ & $2 \cdot 3 \pm 1 \cdot 8$ & $234 \pm 83$ & $5 \cdot 1 \pm 2 \cdot 6$ \\
\hline
\end{tabular}

Units are: SGOT: Sigma Frankel units. CPK: International units. LDH: Berger-Broida units. Aldolase: Sibley-Lehringer units.

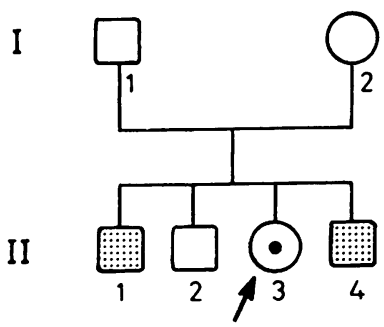

\section{Affected}

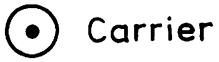

FIG. 2. Family pedigree of case 2, P.C. (arrow). serum CPK estimations between 1.7 and 2.2 with a mean of 2 i.u. (normal mean for age $+\mathrm{SD}=5 \cdot 1$ i.u.). Her aldolases varied between 2.9 and 3.6 with a mean of 3.4 units (normal mean for age $+2 \mathrm{SD}=$ 6.3). Muscle biopsy showed no histological abnormalities.

M.J. herself had only two serum determinations, listed in Table 1. EMG was normal. Light microscopic examination of a muscle biopsy revealed occasional segmental myofibre degeneration, phagocytosis, and myofibre regeneration, findings compatible with a carrier state of DMD.

CASE 2 P.C. (see $\mathrm{II}_{3}$ in Fig. 2) had two brothers with DMD. One of them died at the age of 16 years, the other brother was no longer ambulatory when last seen at the age of 10 years. Serum enzyme studies, electromyography, and muscle biopsy of both patients were compatible with the clinical diagnosis of DMD. The maternal grandmother, mother, and one brother are free of clinical symptoms with normal SGOT, CPK, aldolase, and LDH (one serum sample only was studied of the grandmother and the brother; the serum of the mother was examined twice).

P.C. at the age of 8 years was clinically sympton o⿱ free. Her EMG revealed an unusual number of shore duration, low voltage, polyphasic potentials. Muscle biopsy obtained from the right tibialis anteriog muscle revealed moderate variability of fibre size slight endomysial fibrosis, and occasional centra植. nuclei. Serum enzymes were elevated (Table 1).

CASES 3 AND 4 E.W. and M.W. (Fig. 3, IV $\mathrm{IV}_{2}$ and $\mathrm{IV}_{4}$ ) are daughters of a genealogically true carrier. Both revealed normal EMG, muscle histology by light microscopic examination, and serum SGOT, CPK and aldolase. LDH (two examinations of each proband) were very slightly elevated (Table 1). E.W. had a 7 year old son and a 3 year old daughter who are both clinically normal and show normal SGOT, CPK, aldolase, and LDH.

CASE 5 G.W. is a 55 year old true carrier of the mutant gene (Fig. 3, $\mathrm{III}_{5}$ ). She is the mother of cases 3 and 4. Physical examination, electromyography, and muscle biopsy studied by light microscopy were normal as were her SGOT and aldolase. Her LDH was slightly elevated and her CPK was moderately elevated (Table 1).

The elevated CPK levels of case 5 are in accord with the true carrier state of this woman, although EMG and light microscopy did not reveal any abnormalities. Theoretically her two daughters have a $50 \%$ risk of carrying the mutant gene. Clinical 


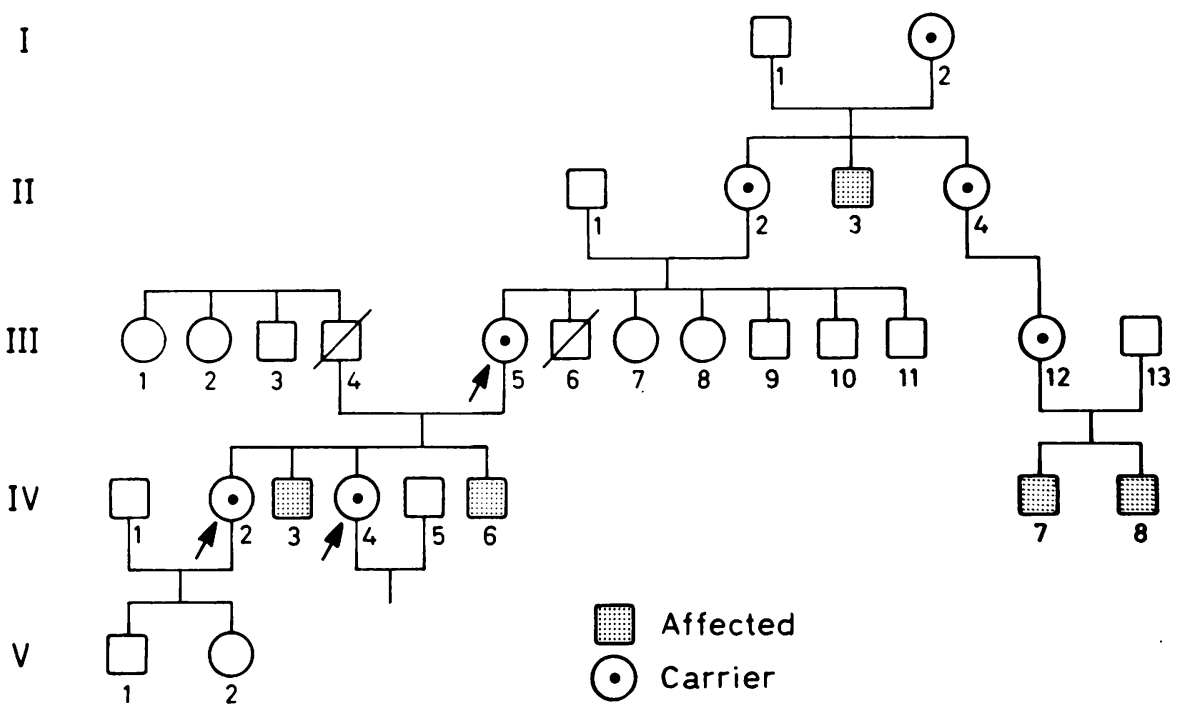

FIG. 3. Family pedigree of case 3, E.W., IV $V_{2}$; case 4, M.W., IV $V_{4}$; and case 5, G.W., III .

TABLE 2

CARRIERS OF DUCHENNE TYPE MUSCULAR DYSTROPHY: LIGHT MICROSCOPIC FINDINGS

\begin{tabular}{|c|c|c|c|c|c|c|c|}
\hline Case & $\begin{array}{l}\text { Variation in } \\
\text { fibre size }\end{array}$ & Nuclei & $\begin{array}{c}\text { Segmental } \\
\text { degeneration }\end{array}$ & Regeneration & Fibrosis & Phagocytosis & Diagnosis \\
\hline $\begin{array}{l}\text { M.J. } \\
\text { P.C. }\end{array}$ & $\begin{array}{l}\text { Moderate } \\
\text { Moderate }\end{array}$ & $\begin{array}{l}\text { Central } \\
\text { Occasionally } \\
\quad \text { central }\end{array}$ & $\begin{array}{l}\text { Occasional } \\
\text { Absent }\end{array}$ & $\begin{array}{l}\text { Present } \\
\text { Absent }\end{array}$ & $\begin{array}{l}\text { Absent } \\
\text { Mild }\end{array}$ & $\begin{array}{l}\text { Rare } \\
\text { Absent }\end{array}$ & $\begin{array}{l}\text { Mild myopathy } \\
\text { Minimal histological } \\
\text { changes }\end{array}$ \\
\hline E.W. & Absent & Normal & Absent & Absent & Absent & Absent & Normal \\
\hline M.W. & ", & $"$ & ", & ", & , & ", & ", \\
\hline
\end{tabular}

TABLE 3

CARRIERS OF DUCHENNE TYPE MUSCULAR DYSTROPHY: ELECTRON MICROSCOPIC FINDINGS

\begin{tabular}{|c|c|c|c|c|c|c|c|c|c|}
\hline Case & $\begin{array}{c}\text { Mitochondrial } \\
\text { aggregates }\end{array}$ & $\begin{array}{c}\text { Abnormal } \\
\text { mitochondria }\end{array}$ & $\begin{array}{l}\text { Myelin } \\
\text { figures }\end{array}$ & $\begin{array}{l}\text { Dilated } \\
\text { SR sacs }\end{array}$ & $\begin{array}{c}\text { Rowing of } \\
\text { nuclei }\end{array}$ & $\begin{array}{c}\text { Central } \\
\text { nuclei }\end{array}$ & $\begin{array}{c}\text { Abnormal } \\
\text { Z-line }\end{array}$ & $\begin{array}{c}\text { Loss of } \\
\text { myofilaments }\end{array}$ & Lysosomes \\
\hline M.J. & & & & + & & + & & & \\
\hline P.C. & . $\quad+$ & & & & & + & + & + & \\
\hline E.W. & + & & & + & & & & + & + \\
\hline M.W. & + & & & & + & & + & + & + \\
\hline G.W. & + & + & + & + & + & + & + & + & + \\
\hline
\end{tabular}

evaluation, electromyography, light microscopy of muscle, and serum enzyme studies did not reveal evidence of a carrier state, although the latter is not excluded by these findings.

Cases 1 and 2 although being possible carriers genealogically show ample laboratory evidence that they indeed are heterozygotes for the DMD gene.

\section{METHODS}

Muscle biopsies were obtained from five carriers of 
the gene for Duchenne muscular dystrophy. Part of each was fixed in $10 \%$ formol saline and embedded in paraffin. Ten micra sections were stained with haematoxylin and eosin (H and E), PAS, and PTAH for light microscopy. Another part of the biopsy specimen was fixed stretched in $3 \%$ buffered glutaraldehyde for one hour, postfixed in $1 \%$ buffered osmium tetroxide, dehydrated in acetone, and embedded in Araldite or Epon 812. One micron thick plastic embedded sections were stained with PTAH-PAS method modified for plastic embedded sections. $600 \AA$ unit sections were obtained using LKB or Sorvall Ultratomes, and glass or diamond knives. They were stained with uranyl acetate and lead citrate and examined in RCA EMU 3G and 4 electron microscopes at $50 \mathrm{kV}$.

\section{RESULTS}

LIGHT MICROSCOPIC OBSERVATIONS These have been presented with the clinical data and in Table 2.

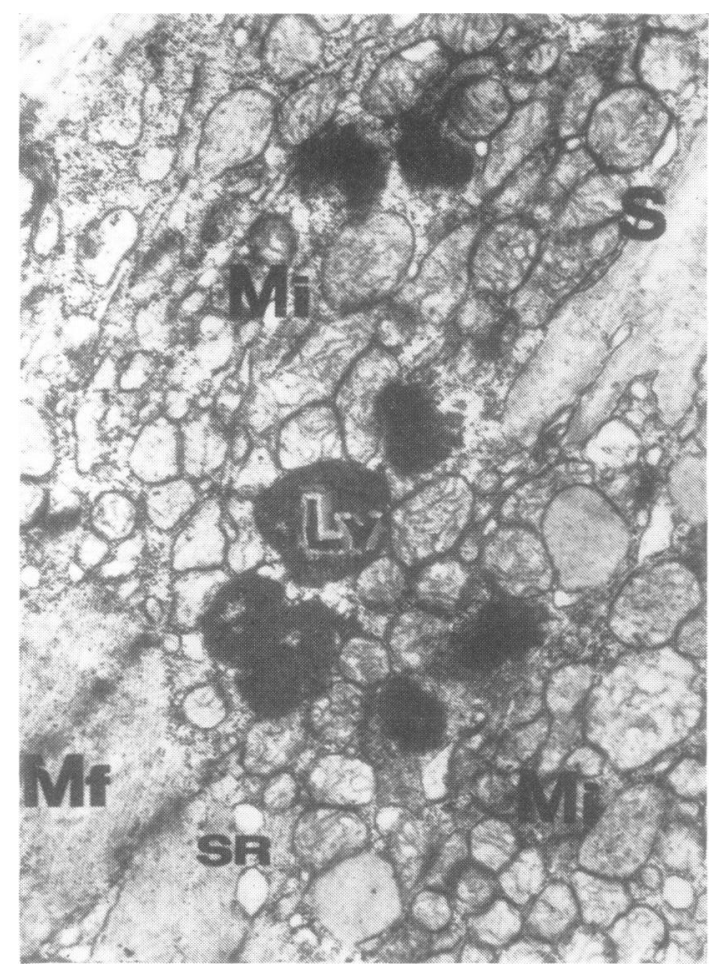

FIG. 4. Electron micrograph showing subsarcolemmal mitochondrial aggregates (Mi) intermixed with lysosomes (Ly). Profiles of dilated sarcoplasmic reticulum (SR) are seen. Mf: myofibril, S: sarcolemma. $\times 17,400$.
ELECTRON MICROSCOPIC OBSERVATIONS Ultrastructural abnormalities were seen in all five biopsies (Table 3 ) and involved the contractile apparatus as well as subcellular organelles.

Massive aggregates of normal appearing subsarcolemmal mitochondria were seen in four biopsies (Fig. 4). They were associated with dense osmiophilic bodies and lipid droplets. The sarcolemma overlying such aggregates was excessively infolded. Scattered among the mass of normal mitochondria were few large mitochondria whose cristae were widely separated, rendering the intercristal space less dense. In some fibres, subsarcolemmal mitochondrial aggregates consisted predominantly of paracrystalline mitochondria, some of which were long and slender. Each mitochondrion contained from two to four paracrystalline inclusions separated from each other by 90 to $240 \AA$ space. The distance between the outermost inclusion and the outer mitochondrial membrane measured $690 \AA$. The limiting membrane of each inclusion measured $60 \AA$, while the mitochond $\stackrel{\$}{\stackrel{D}{\omega}}$ rial limiting membrane measured $120 \AA$ (Fig. 5) $\stackrel{\stackrel{9}{\circ}}{\circ}$ 의

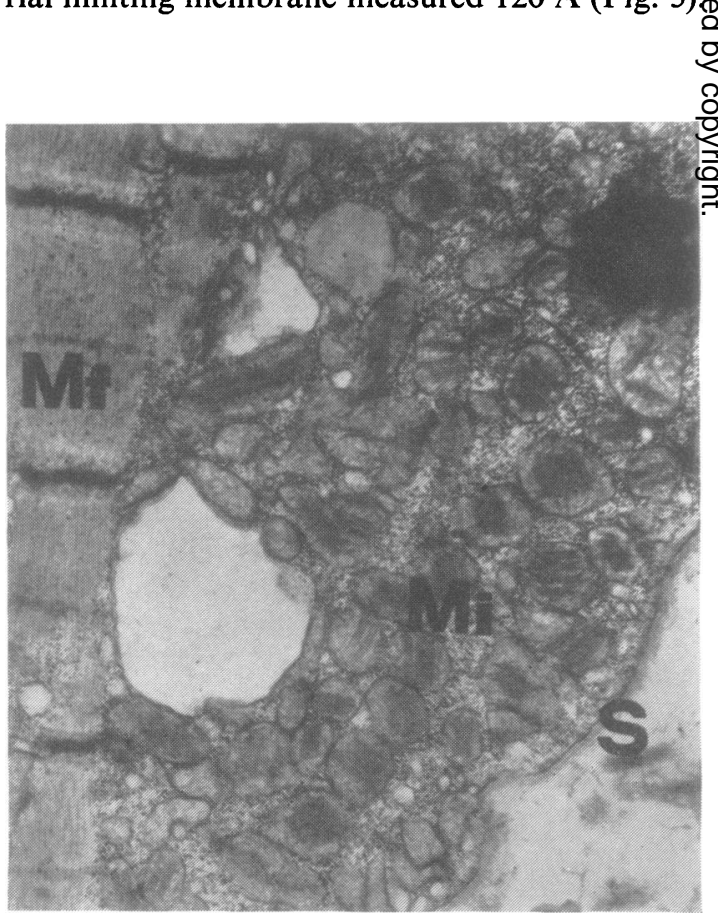

FIG. 5. Electron micrograph showing paracrystalline mitochondria (Mi) in subsarcolemmal location. Mf: Myofibril, S: sarcolemma. $\times 20,300$. 
In an occasional paracrystalline mitochondrion the intercristal space was less dense and contained ghosts of paracrystalline inclusions. Lipid droplets and glycogen were scattered among mitochondria. Although mitochondrial aggregates were more abundant in subsarcolemmal sites, some were seen between myofibrils.

Nuclear alterations consisted of arrangement of subsarcolemmal nuclei in rows in two cases and centralization of nuclei in three cases. Nucleoli were prominent. Nuclear membranes were deeply invaginated. Some nuclei were bisected by deep invaginations (Fig. 6). Centrally placed nuclei were adjacent to mitochondria and dilated sacs of sarcoplasmic reticulum profiles. Densely osmiophilic lysosomal-like bodies were seen in close proximity to such nuclei.

Abnormalities of the $\mathrm{Z}$ line were seen in three cases. They varied from localized widening and irregularity of the $Z$ line to extensive streaming of the $\mathrm{Z}$ line (Fig. 7) with obliteration of the

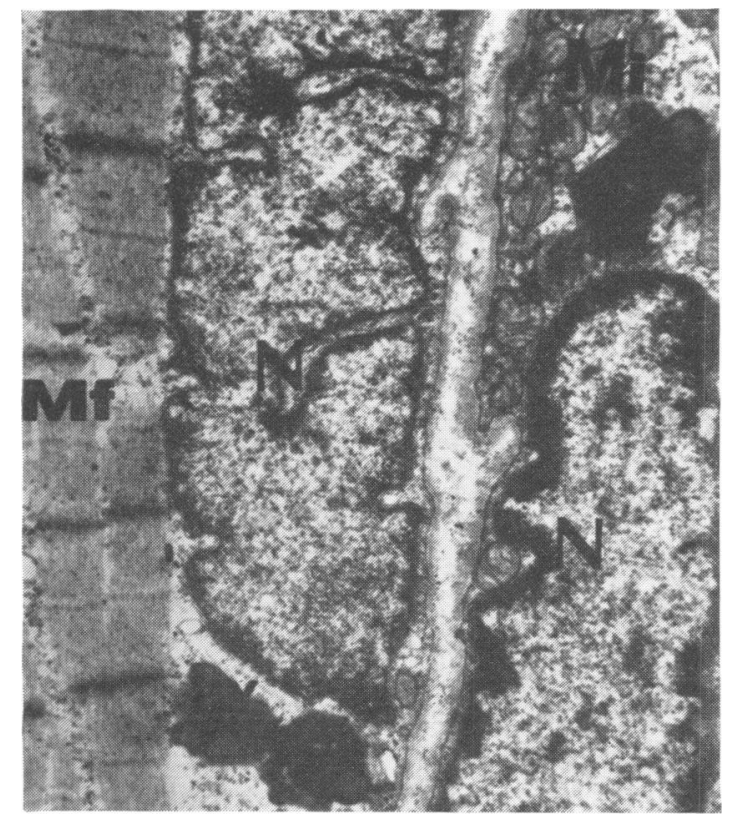

FIG. 6. Electron micrograph showing deeply indented nuclear membranes (N). Mf: Myofibril. Ly: lysosomes. Mi: Mitochondrial aggregates with paracrystalline inclusions. $\times 22,800$. normal banding pattern and of sarcomeral structure. Streaming $\mathrm{Z}$ lines spanned the distance across two or more sarcomeres. Myofilaments in areas of $Z$ line streaming were either absent or scattered haphazardly. The normal myofibrillar structure in such areas was completely disrupted. In addition to myofibrillar alterations associated with $\mathrm{Z}$ line abnormality, four cases showed a minor degree of focal myofilamentous loss or disarray. Otherwise the architecture of the contractile apparatus was generally preserved.

Dilated sacs of longitudinal sarcoplasmic reticulum profiles were seen in three biopsies. Some were located between myofibrils in close proximity to the $\mathrm{Z}$ line and infrequently were related to a mitochondrion. Others surrounded groups of central nuclei separating them from the adjacent contractile apparatus, and some were seen in subsarcolemmal sites.

Myelin-like figures were seen in one case. They were aggregated underneath the sarcolemma in

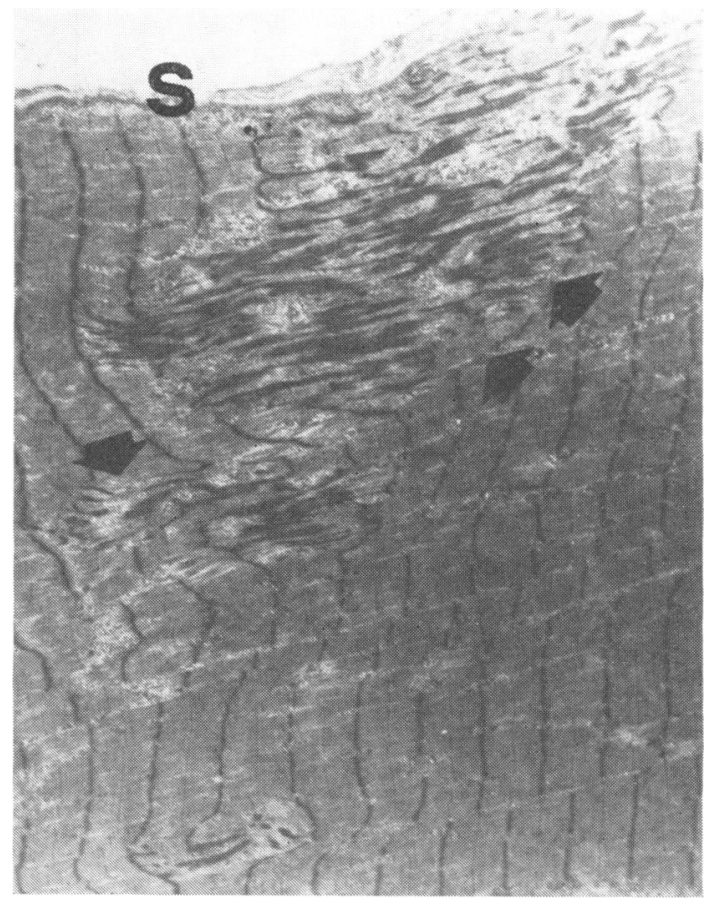

FIG. 7. Electron micrograph showing streaming of $Z$ line (arrow). S: sarcolemma. $\times 4,500$. 
TABLE 4

ELECTRON MISCROSCOPY (EM) AND CARRIERS OF DUCHENNE TYPE MUSCULAR DYSTROPHY

\begin{tabular}{lcccc}
\hline Reference & \multicolumn{4}{c}{ Number of carriers } \\
\cline { 2 - 5 } & $\begin{array}{c}\text { EM } \\
\text { abnor- } \\
\text { malities } \\
\text { only }\end{array}$ & $\begin{array}{c}\text { EM } \\
\text { and other } \\
\text { abnor- } \\
\text { malities* }\end{array}$ & $\begin{array}{c}\text { Normal } \\
\text { EM }\end{array}$ & Total \\
\hline $\begin{array}{c}\text { Beckmann, Kloke, and } \\
\text { Freund-Mölbert (1970) }\end{array}$ & 1 & 1 & 0 & 2 \\
$\begin{array}{c}\text { Hudgson, Pearce, and } \\
\text { Walton (1967) }\end{array}$ & 0 & 2 & 0 & 2 \\
$\begin{array}{c}\text { Ketelsen, Freund-Mölbert, } \\
\text { and Beckmann (1970) }\end{array}$ & 0 & 2 & 0 & 2 \\
$\begin{array}{c}\text { Milhorat, Shafiq, and } \\
\text { Goldstone (1966) }\end{array}$ & 2 & 11 & 4 & 17 \\
$\begin{array}{c}\text { Smith, Amick, and } \\
\text { Johnson (1966) }\end{array}$ & 0 & 2 & 0 & 2 \\
\hline
\end{tabular}

* Enzymes, EMG, histopathology.

close association with dilated sacs of sarcoplasmic reticulum.

Heterogeneous, dense, osmiophilic, lysosomallike bodies were seen in three biopsies. They were seen mainly in subsarcolemmal sites or around central nuclei. They were surrounded by a limiting membrane and contained dense bodies of varying sizes and densities.

A summary of the electron microscopic findings in each case is presented in Table 3.

\section{DISCUSSION}

Recognition of the carrier of the gene for Duchenne type muscular dystrophy is of paramount importance in genetic counselling. An exact family history and pedigree analysis are mandatory and allow distinction of four types of carrier state: (1) true, proven or definite carrier;
TABLE 5

ELECTRON MICROSCOPIC CONFIRMATION OF CARRIER STATE OF DUCHENNE DYSTROPHY

\begin{tabular}{|c|c|c|}
\hline Reference & $\begin{array}{l}\text { No. of } \\
\text { carriers }\end{array}$ & Electron microscopic findings \\
\hline $\begin{array}{l}\text { Beckmann, Kloke, and } \\
\text { Freund-Mölbert (1970) }\end{array}$ & 1 & $\begin{array}{l}\text { Loss of myofilaments, prominent } \\
\text { sarcoplasmic reticulum profiles, } \\
\text { lysosomes }\end{array}$ \\
\hline $\begin{array}{l}\text { Hudgson, Pearce, and } \\
\text { Walton (1967) }\end{array}$ & 2 & $\begin{array}{l}\text { Variation in myofibrillar size, } \\
\text { widening of Z-line, coagulative } \\
\text { necrosis, large convoluted } \\
\text { mitochondria, dilated sarco- } \\
\text { plasmic reticulum profiles, } \\
\text { lipid and dense bodies, myelin } \\
\text { bodies }\end{array}$ \\
\hline $\begin{array}{l}\text { Ketelsen, Freund-Mölbert, } \\
\text { and Beckmann (1970) }\end{array}$ & 2 & $\begin{array}{l}\text { Myofibrillar degeneration, widen- } \\
\text { ing and proliferation of Z-line, } \\
\text { loss of mitochondria, promin- } \\
\text { ence of sarcoplasmic reticulum } \\
\text { profiles, regenerative attempts }\end{array}$ \\
\hline $\begin{array}{l}\text { Milhorat, Shafiq, and } \\
\text { Goldstone (1966) }\end{array}$ & 11 & $\begin{array}{l}\text { Focal fibrillar and hyaline de- } \\
\text { generation, regenerative } \\
\text { attempts, satellite cells }\end{array}$ \\
\hline $\begin{array}{l}\text { Smith, Amick, and } \\
\text { Johnson (1966) }\end{array}$ & 2 & $\begin{array}{l}\text { Focal subsarcolemmal myo- } \\
\text { fibrillar degeneration }\end{array}$ \\
\hline
\end{tabular}

(2) probable carrier; (3) possible carrier, types and $\mathrm{B}$.

On the basis of the pedigree studies, case 1 is possible carrier, type $\mathrm{B}$; cases 2,3 , and 4 ar 8 possible carriers, type $A$; and case 5 is a true o definite carrier of the mutant gene. A variety of. methods to detect carrier state have been de scribed and their relative values have been critically reviewed by Gardner-Medwin, Pennington, and Walton (1971). The need to search for newer methods to detect carriers becomes apparent when one examines the yield of presently used methods. Approximately twothirds of female carriers can be detected utilizing serum creatine phosphokinase alone. Probably up to one half of the remaining can be identified

TABLE 6

DETECTION OF CARRIERS OF DUCHENNE TYPE MUSCULAR DYSTROPHY BY ELECTRON MISCROSCOPY

\begin{tabular}{|c|c|c|c|c|}
\hline Reference & Carriers & Type of carrier & Normal studies & EM findings \\
\hline $\begin{array}{l}\text { Beckmann, Kloke, and } \\
\text { Freund-Mölbert (1970) }\end{array}$ & 1 & Possible & $\begin{array}{l}\text { 1. Enzymes } \\
\text { 2. Histopathology } \\
\text { 3. Electromyography }\end{array}$ & $\begin{array}{l}\text { Homogenization of myofibril, increase in mito- } \\
\text { chondria, glycogen, and collagen fibrils }\end{array}$ \\
\hline \multirow{2}{*}{$\begin{array}{l}\text { Milhorat, Shafiq, and } \\
\text { Goldstone (1966) }\end{array}$} & 1 & Possible & CPK & Focal fibrillar degeneration \\
\hline & 1 & Definite & CPK & Focal fibrillar degeneration, occasional regeneration \\
\hline
\end{tabular}


by means of presently available electromyographic methods and/or muscle histology. There remain a small number of women known to be carriers on genetic grounds in whom the results of all investigations are normal. It is thus not possible completely to reassure a young woman who presents herself for these tests that if they are all negative, there is no chance of her having a dystrophic child.

There are comparatively few electron microscopic studies in carriers (Milhorat, Shafiq, and Goldstone, 1966; Smith, Amick, and Johnson, 1966; Hudgson, Pearce, and Walton, 1967; Beckmann, Kloke, and Freund-Mölbert, 1970; Ketelsen, Freund-Mölbert, and Beckmann, 1970). We have studied muscle biopsies from 25 carriers. Ultrastructural abnormalities were reported in all except four probable carriers (Table 4). Of the 21 carriers with ultrastructural abnormalities, 18 could have been detected by tests less elaborate and less expensive than electron microscopy, such as clinical examination, electromyography, and muscle histopathology. In all of them electron microscopy confirmed the diagnosis of carrier state (Table 5). In the remaining three, the diagnosis of carrier state could not have been established without electron microscopy (Table 6).

Ultrastructural alterations reported in muscle from carriers include focal areas of myofibrillar loss, homogenization of myofibrils, widening of $\mathrm{Z}$ line, increase and dilatation of elements of sarcoplasmic reticulum, large and convoluted mitochondria, degeneration or loss of mitochondria, myelin bodies, lipid and lysosomal bodies, increase in glycogen, and attempts at regeneration.

Electron microscopic findings in our cases are in agreement with those in the literature. Mitochondrial aggregates were concentrated in subsarcolemmal regions and most of them were normal. The paracrystalline mitochondria seen in one of our cases have not been described before in carriers. Paracrystalline mitochondria were first described by Shy, Gonatas, and Perez (1966) in a case of megaconial myopathy. They have since been reported in several other conditions (Norris and Panner, 1966; Afifi, Ibrahim, Bergman, Abu Haydar, Mire, Bahuth, and Kaylani, 1972). They are thus not specific to any myopathy but may reflect a pathological reaction of mitochondria. Aggregates of normal mitochondria similar to those seen in our cases and reported in the literature in carriers probably reflect a reaction of the muscle to increased metabolic demand (Luft, Ikkos, Palmieri, Ernster, and Afzelius, 1962) and may correlate with the active regenerative attempts described in the histology of muscle in carriers. Similar aggregates of mitochondria have been described in a variety of muscular disorders (Afifi, Aleu, Goodgold, MacKay, 1966; Zellweger, Afifi, McCormick, and Mergner, 1967; Afifi and Bergman, 1969; Afifi and Zellweger, 1969).

$\mathrm{Z}$ line abnormalities seen in three of our cases are similar to those reported by Hudgson et al. (1967) and Ketelson et al. (1970). The Z line changes described by Hudgson et al. (1967) occurred in otherwise intact fibres, suggesting that they reflect early changes in the pathological process. Streaming and irregularity of the $\mathrm{Z}$ line was first described in central core disease (Seitelberger, Wanko, and Gavin, 1961; Shy, Engel, and Wanko, 1962). They have since been described in a variety of neuromuscular disorders (Milhorat et al., 1966; Afifi and Zellweger, 1969) suggesting that they too are nonspecific reactions of muscle fibres in disease states.

The myofilamentous loss and disarray seen in our cases are similar to those described in the literature in being focal and patchy in nature. They could be easily missed in histological sections studied by light microscopy. The scattered focal nature and moderate severity of ultrastructural changes seen in these carriers support the notion of 'subclinical disease' in carriers and favour the Lyon hypothesis (1963) in muscular dystrophy carriers. The dilatation and prominence of sarcoplasmic reticulum profiles near to nuclei described in three of our cases confirm similar observations by Hudgson et al. (1967) and Ketelsen et al. (1970). Hudgson et al. (1967) noted close proximity of prominent sarcoplasmic reticulum profiles to regions of altered $Z$ lines and myofilaments. They speculated that alterations in the $\mathrm{Z}$ line and myofilaments may be induced by the presence in their immediate vicinity of dilated elements of sarcotubular system which may be in fact 'activated lysosomes'.

Lysosomal dense bodies and myelin bodies 
were present in our cases as in those reported by Hudgson et al. (1967). They may represent early products of destruction of the muscle fibre.

We did not observe the loss of mitochondria described by Ketelsen et al. (1970) or the regenerative attempts described by Milhorat et al. (1966) and Ketelsen et al. (1970). The nuclear alterations described in our material, on the other hand, have not been reported in the literature in carriers.

The electron microscopic findings in muscle from our five carriers and others reported in the literature speak for a possible role of electron microscopy in the detection of carriers of the gene for muscular dystrophy. Cases 1, 2, and 5 show clear laboratory evidence of the carrier state. In them the electron microscopic changes support the diagnosis of carrier state as determined by other methods. Cases 3 and 4 have, genealogically speaking, a $50 \%$ chance of being carriers, yet no laboratory evidence is available to support the diagnosis of carrier state except for the electron microscopic changes as in the three cases reported by Beckman et al. (1970) and Milhorat et al. (1966).

These findings suggest that a female carrier by genetic criteria with normal CPK, electromyography, and muscle histology should not therefore be assured of normality unless her muscle is studied by electron microscopy. Only when all available methods of study are exhausted can one hope to detect the greatest majority of carriers and only then to prevent this most disabling disease by proper genetic counselling. Obviously many more electron microscopic observations are needed before this tool can be confidently used for recognition of the carrier state.

\section{REFERENCES}

Afif, A. K., Aleu, F. P., Goodgold, J., and MacKay, B. (1966). Ultrastructure of atrophic muscle in amyotrophic lateral sclerosis. Neurology (Minneap.), 16, 475-481.

Afif, A. K., and Bergman, R. A. (1969). Steroid myopathy. A study of the evolution of the muscle lesion in rabbits. Johns Hopkins Medical Journal, 124, 66-86.
Afifi, A. K., Ibrahim, M. Z. M., Bergman, R. A., Abu Haydar, N., Mire, J., Bahuth, N., and Kaylani, F. (1972). Morphologic features of hypermetabolic mitochondrial disease. Journal of Neurological Sciences, 15, 271-290.

Afifi, A. K., and Zellweger, H. (1969). Pathology of muscular hypotonia in the Prader-Willi syndrome. Journal of Neurological Sciences, 9, 49-61.

Beckmann, R., Kloke, W. D., and Freund-Mölbert, E. R. G. (1970). Ultrastructural findings in 'carriers' of Duchenne muscular dystrophy. In Muscle Diseases, pp. 439-444. Edited by J. N. Walton, N. Canal, and G. Scarlato International Congress Series 199. Excerpta Medica: Amsterdam.

Gardner-Medwin, D., Pennington, R. J., and Walton, J. N. (1971). The detection of carriers of X-linked muscular dystrophy genes. A review of some methods studied in Newcastle upon Tyne. Journal of Neurological Sciences, 13, 459-474.

Hudgson, P., Pearce, G. W., and Walton, J. N. (1967). Preclinical muscular dystrophy: histological changes observed on muscle biopsy. Brain, 90, 565-576.

Ketelsen, U. P., Freund-Mölbert, E., and Beckmann, R. (1970). Feinstrukturelle Untersuchungen der Muskulatur bei Duchenne-Muskeldystrophie zur Identifizierung von Konduktorinnen. Die myofibrilläre Degeneration. Beiträge zur Pathologie, 141, 123-141.

Luft, R., Ikkos, D., Palmieri, G., Ernster, L., and Afzelius, B. (1962). A case of severe hypermetabolism of nonthyroidv origin with a defect in the maintenance of mitochondria $\bar{B}$ respiratory control. Journal of Clinical Investigation, $41, \mathbb{D}$ 1776-1804.

Lyon, M. F. (1963). Attempts to test the inactive-X theory of dosage compensation in mammals. Genetical Research 4, 93-103.

Milhorat, A. T., Shafiq, S. A., and Goldstone, L. (1966) Changes in muscle structure in dystrophic patients, carriers and normal siblings seen by electron microscopy은 Annals of the New York Academy of Sciences, 138, 246-292?

Norris, F. H., Jr., and Panner, B. J. (1966). Hypothyroid myopathy. Archives of Neurology, 14, 574-589.

Seitelberger, F., Wanko, T., and Gavin, M. A. (1961). The muscle fiber in central core disease. Histochemical and electron microscopic observations. Acta Neuropathologica, 1, 223-237.

Shy, G. M., Engel, W. K., and Wanko, T. (1962). Central core disease: a myofibrillary and mitochondrial abnormality of muscle. Annals of Internal Medicine, 56, 511-520.

Shy, G. M., Gonatas, N. K., and Perez, M. (1966). Two childhood myopathies with abnormal mitochondria. 1. Megaconial myopathy. 2. Pleoconial myopathy. Brain, 89, 133-158.

Smith, H. L., Amick, L. D., and Johnson, W. W. (1966). Detection of subclinical and carrier states in Duchenne muscular dystrophy. Journal of Pediatrics, 69, 67-79.

Zellweger, H., Afifi, A. K., McCormick, W. F., and Mergner, W. (1967). Benign congenital muscular dystrophy. Clinical Pediatrics, 6, 655-663. 